\title{
Corporate Social Responsibility Regulation in the Indonesian Mining Companies
}

\author{
Dian Anita NUSWANTARA ${ }^{1}$, Dhea Ayu PRAMESTI ${ }^{2}$
}

Received: July 30, 2020 Revised: August 23, 2020 Accepted: August 29, 2020

\begin{abstract}
The condition of mining companies that exploit natural resources in their business processes underline this research to emphasize on social and environmental issues. After twelve years of government regulation on CSR practices, this study investigates the factors that influence mining companies in disclosing information about corporate social responsibility based on legitimacy, stakeholders, and agency theory. Thus, independent variables are foreign ownership, company size, leverage, and the board of commissioners. The dependent variable is the corporate social reporting disclosure that is measured using GRI indexing. For sampling, we have used thirty-four Indonesian mining companies listed in IDX during the 2014-2018. out of which only fifty-two companies meet the sample criteria. All data should pass the classical assumption test to get the best estimator. Multiple linear regression is used to test the hypothesis, and the results show that the model is good, and can explain $60 \%$ of the dependent variable. Based on F-test, all four variables affect CSR practices simultaneously. The findings of this study suggest that foreign ownership and firm size influences CSR disclosure in a positive direction. However, this study did not support the hypothesis that leverage negatively affects CSR disclosure and board size measures positively affect CSR disclosure.
\end{abstract}

Keywords: Foreign Ownership, Corporate Social Responsibility, Agency Theory, Board of Commissioner, CSR Disclosure, Mining Companies

JEL Classification Code: G30, G32, M41, M48

\section{Introduction}

The contribution of Mining companies in Indonesia's GDP in the second quarter of 2018 and 2019 , amounts to $7.77 \%$ and 7.38\% respectively (Priyanka, 2019). Besides, labor absorbed in 2017 amounted to 935,753 (Central Bureau of Statistics, 2017). On the other hand, people around the business still felt the negative impact of excessive use of mining and natural resources. According to the Ministry of Environment and Forestry, during 2017-2018, eleven mining companies were found guilty of polluting the environment and were subjected to different sanctions (Amelia, 2019). It was made clear that a company should not only serve the interests of internal parties

${ }^{1}$ First Author and Corresponding Author. Lecturer, Department of Accounting, Faculty of Economics, Universitas Negeri Surabaya, Indonesia [Postal Address: Kampus Unesa Ketintang, Surabaya, East Java, 60231, Indonesia] Email: diananita@unesa.ac.id ${ }^{2}$ Department of Accounting, Faculty of Economics, Universitas Negeri Surabaya, Indonesia.

Email: dheapramesti16080694032@mhs.unesa.ac.id

(C) Copyright: The Author(s)

This is an Open Access article distributed under the terms of the Creative Commons Attribution Non-Commercial License (https://creativecommons.org/licenses/by-nc/4.0/) which permits unrestricted non-commercial use, distribution, and reproduction in any medium, provided the original work is properly cited. such as the management and the shareholders, but also must pay attention to the environment and interests of the people. When it is done, then the company can run its business activities properly without causing conflict with the community or the surrounding environment. Companies need to provide information about corporate social and environmental responsibility (Hidayat, 2017). In line with the theory of legitimacy, the disclosure of Corporate Social Responsibility (CSR) aims to convince stakeholders that the company has been operating according to the norms and rules of the society.

Increased industrial activity in Indonesia has also resulted in broader impacts. The negative impact arising from industrial activities in Indonesia has compelled the government, the community, and business people to make regulations regarding the implementation and disclosure of CSR. According to Kotler and Lee (2005), CSR is a company's commitment to improve society's welfare through the contribution of company resources and suitable business activities. CSR includes activities in the economic, social, and environmental fields. The form of responsibility can be in the form of environmental improvement, improvement in the quality of employees, and the community through the awarding of scholarships and contributions to improving the infrastructure of the surrounding area (Carroll, 1991). 
Disclosure of CSR has been regulated in Law of the Republic of Indonesia number 40 of 2007, article 66, and paragraph $2 \mathrm{C}$ concerning Limited Liability Companies, which explains the directors' obligation to disclose CSR in the annual report. Although the regulation has been in force for 12 years, the majority of companies in Indonesia are still not aware of the importance of doing CSR. Referring to the news reported by Kompas (2016), Abdul Malik, one of the Representatives of Commission VIII of the Indonesian House of Representatives says that even though laws relating to the implementation and disclosure of CSR already exist, in terms of accountability and transparency, CSR activities are still considered low. CSR disclosure in the annual report is still lacking as there are no specific regulations that explain the disclosure of CSR information in detail and as a result the form and content in CSR reports tend to be varied. In line with the research of Jain et al. (2015) that there is no explicit legislative control regarding CSR reporting in Asia Pacific countries.

Based on Law of the Republic of Indonesia No. 40 of 2007 concerning Limited Liability Companies article 74 paragraph 1, companies whose operational activities have an impact on natural resources must carry CSR activities. Mining companies are one of the sectors that deal directly with natural resources with specific laws related to CSR. According to Law of the Republic of Indonesia No. 4 of 2009 concerning Mineral and Coal Mining, holders of Mining Business Licenses are required to arrange community development and empowerment. Although CSR is a little different from the Limited Liability Company Law, the core of Law of the Republic of Indonesia No. 4 of 2009 is aimed at the interests of the surrounding community.

Research in 2016 by the National University of Singapore (NUS) Business School, showed that based on items issued by the Global Reporting Initiative (GRI), the quality of reporting and CSR practices in Indonesia ranked third with a value of 48.4 after Thailand $(56,8)$ and Singapore $(48.8)$. These results indicate that Indonesia's concern regarding CSR is still relatively low compared to other Asian countries (Suastha, 2016).

Several factors influence the extent of CSR disclosure, including foreign ownership, size, leverage, and size of the board of commissioners. Research Hu et al. (2016) in China found that foreign ownership plays an essential role in making decisions regarding CSR disclosure. Likewise, Sunreni (2016) found that foreign ownership in mining companies affected CSR disclosure. At the same time, Waluyo (2017) and Giannarakis (2014) found that size had a significant effect on CSR disclosure. Besides, Oktavianawati and Wahyuningrum (2019) and Habbash (2016) found that leverage has a significant effect on CSR disclosure. Chelsya (2018) and Hermawan and Gunardi (2019) study found a significant influence on the size of the board of commissioners' variables on CSR disclosure.
Following 12 year implementation of CSR disclosure, it is crucial to examine further the effect of foreign ownership, size, leverage, and size of the board of commissioners on CSR disclosure in the mining sector listed on the Stock Exchange.

\section{Literature Review}

\subsection{Legitimacy Theory}

Legitimacy is the alignments of individuals or organizations sensitive to the state of the surrounding environment by focusing on relations with the community so that operational activities are following the existing norms and rules system in the community (Mousa \& Hassan, 2015). By considering being legitimate, the company's business activities can be sustainable without any restrictions from the surrounding community.

In line with the theory of legitimacy, companies need to develop CSR programs and express them so that the community believes and can accept the company's presence well. This is due to the fact that a company's activity can be influenced or be influenced by the community (Novitasari \& Bernawati, 2020). Likewise, according to Kotler and Lee (2005), companies that comply with surrounding requirements and regulations will be free from the supervision of central and local government entities as well as international community or organizations (Kang \& Hwang, 2018). To avoid monitoring from authorities as well as from the international community, a company needs to disclose their CSR activities to the public. Disclosing their activities will enhance the reputation and legitimacy of the company and avoid rejection of the surrounding community.

\subsection{Stakeholder Theory}

Stakeholders are people or groups of people who have rights and interests in the company's operations and decisions. Management needs to determine who their stakeholders are, including employees, the public, investors, creditors, consumers, and shareholders (Carroll, 1991). According to Nguyen et al. (2020), companies in operation should not only aim for profitability but also must consider the interests of stakeholders. Use of media can be done for CSR implementation and disclosure to communicate CSR activities to management and other stakeholders. In this way, the stakeholders will consider valuable CSR implementation to support the business processes. According to Lee and Kwon (2017), the high CSR performance level contributes to the company's reputation that can attract foreign investors. Thus foreign investors are one of the stakeholders who have a significant influence in making decisions regarding CSR disclosure. Yoon and Lee (2019) prove that more the Korean companies disclosed the CSR information, smaller was the information asymmetry. This means the investor values the CSR information published. 


\subsection{Agency Theory}

According to Jensen and Meckling (1976), agency theory is a contractual engagement between principals and agents to carry out principal's best interests. Agents include suppliers, creditors, shareholders, and managers. However, each of these parties' interests can be different, and the agent will not always act in the best interests of the principal so that it can lead to agency conflict (Waluyo, 2017). That is why supervision is needed so that management does not act adversely. Various proxies can reflect the supervisory role, including lenders who will demand that management not violate the boundaries of the debt agreement.

\subsection{Foreign Ownership and CSR Disclosure}

Stakeholder's theory contended that disclosure is to satisfy the data needs of various stakeholder (Jahid et al., 2020). In line with stakeholder theory, if a company has a trade or ownership agreement with a foreign party, it will disclose CSR-related information more broadly (Asrida, 2011). Do (2017), Hu et al. (2016), and Sunreni (2016) also found that the concerns and responsibilities of foreign shareholders regarding social and environmental issues are profound. Examples of countries that are more concerned with environmental conditions are America and Europe (Sunreni, 2016). Foreign investors from countries with high concern for CSR and the environment will attract the attention of various international communities. Studies by Prahalad and Hammond (2002) and Kang and Hwang (2018) reveal that the international community often criticizes and has issues with a company which has a sizable foreign ownership and multinational market but shows the social welfare program less evident than the profit-orientation.

\subsection{Company Size and CSR Disclosure}

In general, pressure and attention from the public will be higher for large-scale companies. This situation is in line with legitimacy theory, where large companies will incur high costs to realize legitimacy because the pressure for publication of information is higher than smaller companies (Sembiring, 2005). The company needs this legitimacy as an effort to maintain it going forward. Research by Nawaiseh et al. (2015), Waluyo (2017), and Hu et al. (2016) shows the same result which says that the size has a significant effect on CSR disclosure.

\subsection{Leverage and CSR Disclosure}

Based on agency theory, there is a contractual engagement between the principal and agent with different views and interests that can lead to agency conflict (Waluyo,
2017). According to Hermawan and Gunardi (2019), the company's financial risk will increase and become a concern for creditors if the debt level is high. Therefore, companies with high financial risk will minimize costs that can reduce revenue, including costs and activities related to CSR, which will result in a decrease in the extent of CSR disclosure so as not to highlight it to the creditors. This statement is in line with agency theory, which states that the company will try to optimize profits so as not to get more attention from creditors (Oktavianawati \& Wahyuningrum, 2019). Research by Giannarakis (2014), Habbash (2016), and Nawaiseh et al. (2015) shows the same result that variable leverage has a negative effect on the CSR disclosure.

\subsection{Board of Commissioners and CSR Disclosure}

According to the Law of the Republic of Indonesia, No. 40 of 2007 regarding Limited Liability Company article 1 paragraph 6 states that the board of commissioners is a corporate organ that has the authority and responsibility in a company, one of which is to oversee management (directors) in general or specifically in managing the company. The board of commissioners consists of commissioners and independent commissioners (Effendi, 2018). In line with stakeholder theory, if the board of commissioners' size is getting higher, then the role of monitoring can be carried out effectively so that it is easier to control the directors. The pressure faced by management (directors) is also getting bigger. Therefore, with the supervision owned by the board of commissioners', management can present more extensive information about CSR disclosures because the board of commissioners also needs to consider issues related to society, namely the implementation of CSR (Oktavianawati \& Wahyuningrum, 2019). Research by Chelsya (2018), Oktavianawati and Wahyuningrum (2019), and Hermawan and Gunardi (2019) shows the same result that the number of boards of commissioners determine the extent of CSR information disclosure.

H1: Foreign ownership has a positive effect on CSR disclosure

H2: Size has a positive effect on CSR disclosure

H3: Leverage has a negative effect on CSR disclosure

H4: The size of the board of commissioners has a positive effect on CSR disclosure.

\section{Research Method}

This type of research is called quantitative with explanatory research. Type of data used is secondary. All data has been retrieved from www.idx.com in the financial reporting and annual report of mining companies. The sampling criteria are as follows: 
1. To include a mining company that discloses CSR in the 2015-2018 annual report

2. A company which publishes the names of the foreign individuals or institutions shareholders

\subsection{Independent Variables}

\section{Foreign Ownership}

Foreign ownership can be defined as a foreign individual or institution that invests in assets or shares in a company in another country. Foreign parties, especially those from European, Singapore, and America, are considered to have a high sense of concern for the environment and corporate social responsibility (Sunreni, 2016). The foreign ownership variable has been measured by Sunreni (2016) as follows:

$$
\text { Foreign Ownership }=\frac{\text { Foreign ownership }}{\text { Number of shares issued }}
$$

\section{Company Size}

Size is the level of determination of the size of a company and is based on specific indicators. There are values of stocks, sales, log total asset and total employment. The activities carried out by large companies are more complicated so that the effects arising on stakeholders and the environment are also substantial (Cahyani \& Suryaningsih, 2016). The variable size is measured by the natural $\log$ of total assets to get smooth data. It minimizes the significant difference in the size of the company with other variables.

$$
\text { Size }=\text { Natural } \log \text { of total assets }
$$

\section{Leverage}

Leverage is the ratio of debt owed by a company to finance its operations to remain sustainable. The company's financial risk will increase and become a concern for the debtholders if the level of debt held is high. Therefore, companies with high financial risk tend to present higher profits to prevent violations of debt agreement (Oktavianawati \& Wahyuningrum, 2019). The leverage variable is measured by measurements made by Chauhan and Amit (2014) is as follows:

$$
\text { Leverage }=\frac{\text { Total Debt }}{\text { Total Equity }}
$$

\section{Board of Commissioners}

The board of commissioners has the main task of overseeing the company's performance and, if necessary, will provide advice and input to the directors. A company has at least two people who serve on the board of commissioners (Chelsya, 2018). Calculations on the size of the board of commissioners refer to calculations made by Hermawan and Gunardi (2019) as follows:

$$
\mathrm{BOC}=\sum \text { Board of commissioners of the company }
$$

\subsection{Dependent Variable}

CSR Disclosure is a process of communicating the impact of organizations, both positive and negative on the economy, society and the environment. The variables were measured under the Global Reporting Initiative (GRI) G3.1. If an indicator presented in the company annual report, the score was " 1 ", and if not " 0 ". There are 84 indicators, so that the maximum number was 84 points. The variable represents in proportion under the formula used by Chelsya (2018) as follows:

$$
\mathrm{CSR}=\frac{\text { number of CSR items disclosed by the company }}{\text { Total of all items }}
$$

Data were analyzed through the Classical Assumption Test to see the data tested were normal and avoid the problem after the classical assumption requirements were fulfilled. It can be tested for Multiple Linear Regression Analysis to see the relationship between the independent variables and the dependent variable. After that, proceed to test the research hypothesis with the F-Test and the T-Test.

\section{Research Results}

Research samples that have met the criteria are 13 companies with four observation periods, so that the total research sample is 52 (see Table 1).

Table 1: Research Sample

\begin{tabular}{|l|c|}
\hline Description & Total \\
\hline $\begin{array}{l}\text { Companies listed on the IDX during the 2015- } \\
2018 \text { period }\end{array}$ & 34 \\
\hline Companies that do not meet the sample criteria & \\
\hline - Companies that do not have foreign ownership & $(18)$ \\
\hline $\begin{array}{l}\text { - Companies that do not disclose the information } \\
\text { related CSR }\end{array}$ & $(3)$ \\
\hline Total companies each year & 13 \\
\hline Total companies during 2014-2018 & 52 \\
\hline
\end{tabular}




\subsection{Prerequisites of Classical Assumptions}

Table 2 shows that the significance value is 0.200 which means that the tested data are normally distributed because they exceed the specified significance level of 0.05 . Table 2 shows that each variable shows a Tolerance value $>0.10$ and a VIF value $<10$ which means there is no multicollinearity in this test. Table 2 shows that the value of Durbin Watson is 2.191. The appropriate DU value is 1.7228 so that the data is free from the autocorrelation problem. Table 2 shows that the significance value of each variable exceeds the significance level set at 0.05 so that the data is free from heteroscedasticity problems (see Table 2).

\subsection{Hypothesis Testing}

Table 3 shows the multiple linear regression results. As seen from Table 3 , the model explains $60 \%$ of the variation in CSR disclosure. Table 3 also shows that the significance level of 0.000 is $<0.05$, means foreign ownership, size, leverage, and board size are interpreted simultaneously to influence CSR disclosure. Table 3 shows that foreign ownership and size significantly influence CSR disclosure because the significance of the two variables was less than 0.05 . Whereas the variable leverage and size of the board of commissioners showed, the results did not affect CSR disclosure because the significance level was higher than 0.05 (see Table 3).

Table 2: Prerequisites of classical assumptions

\begin{tabular}{|c|c|c|c|c|}
\hline Description & FO & SIZE & LEV & BOC \\
\hline Normality & \multicolumn{4}{|c|}{$0.200>0.05$} \\
\hline $\begin{array}{l}\text { Multicollinearity } \\
\text { Tolerance } \\
\text { VIF }\end{array}$ & $\begin{array}{c}0.870>0.10 \\
1.150<10\end{array}$ & $\begin{array}{c}0.716>0.10 \\
1.397<10\end{array}$ & $\begin{array}{c}0.858>0.10 \\
1.165<10\end{array}$ & $\begin{array}{c}0.669>0.10 \\
1.495<10\end{array}$ \\
\hline $\begin{array}{l}\text { Autocorrelation } \\
\text { Durbin Watson }\end{array}$ & \multicolumn{4}{|c|}{$1.7228(\mathrm{DU})<$ Sig. 2.191} \\
\hline $\begin{array}{l}\text { Heterocedasticity } \\
\text { Glejser test }\end{array}$ & $0.449>0.05$ & $0.338>0.05$ & $0.605>0.05$ & $0.969>0.05$ \\
\hline Scatter Plot & \multicolumn{4}{|c|}{ Irregular spreading point pattern } \\
\hline
\end{tabular}

Table 3: Multiple linear regression result

\begin{tabular}{|c|c|c|c|c|}
\hline \multirow{2}{*}{ Model } & \multicolumn{2}{|c|}{ Unstandardized Coefficients } & \multirow[t]{2}{*}{$\mathbf{t}$} & \multirow[t]{2}{*}{ Sig. } \\
\hline & B & Std. Error & & \\
\hline (Constant) & -1.108 & .213 & -5.211 & .000 \\
\hline FO & .090 & .042 & 2.158 & .036 \\
\hline SIZE & .074 & .011 & 6.607 & .000 \\
\hline LEV & -.016 & .016 & -1.018 & .314 \\
\hline $\mathrm{BOC}$ & .005 & .009 & .619 & .539 \\
\hline R-Squared & \multicolumn{4}{|c|}{.632} \\
\hline Adjusted R Square & \multicolumn{4}{|c|}{.600} \\
\hline S.E.of the Estimate & \multicolumn{4}{|c|}{.09388} \\
\hline F-Statistic & \multicolumn{4}{|c|}{20.156} \\
\hline Prob (F-Statistic) & \multicolumn{4}{|c|}{.000} \\
\hline
\end{tabular}




\section{Discussion}

\subsection{Foreign Ownership and CSR Disclosure}

Companies will disclose their CSR activities more widely if the level of company shares owned by foreign parties is high. The company will try to adjust itself to each stakeholder's wishes, one of which is to fulfill the stakeholder's right to obtain information, both financial and non-financial. CSR is non-financial information aimed at interested parties, including foreign ownership of the company's concern for human rights, the environment, and the economy (Asrida, 2011).

These results are consistent with stakeholder theory; namely, foreign ownership, in this case, is a shareholder who can influence and be influenced by company decisions. In the research of Nguyen and Nguyen (2020) in Vietnam found that the participation of foreign ownership has contributed to increased CSR disclosure. The stronger the position of stakeholders, the higher its influence on the company so that it will preferably consider the interests of its stakeholders in making decisions. Companies whose majority shares are owned by foreign parties will disclose CSR information more widely because foreign countries are more concerned with CSR activities and disclosures (Asrida, 2011). Study by Sunreni (2016) also states that foreign companies such as from Europe, Singapore, and America have more knowledge of CSR concepts and practices so these companies are known to care more about social and environmental issues. The same results were revealed in Do (2017), A. H. Nguyen and Nguyen (2020), and $\mathrm{Hu}$ et al. (2016).

\subsection{Company Size and CSR Disclosure}

Large companies have a greater responsibility in providing information because all activities carried out are more complex and have a more significant effect on stakeholders. If the company wants its activities and survival to continue, stakeholder support is needed. To get support from stakeholders, the company will disclose information more broadly. Following the theory of legitimacy, a company with a bigger size will incur high costs to realize legitimacy because large companies have higher pressure to publish information than companies with a smaller size (Sembiring, 2005). The company needs this legitimacy as an effort to maintain the company going forward. With a large company size, the disclosure of company information related to social activities and the environment will also expand. The same results were revealed in the research of Chelsya (2018), Waluyo (2017) and Cahyani and Suryaningsih (2016).

\subsection{Leverage and CSR Disclosure}

Companies in financing their operations not only depend on the value of assets and equity owned but also require debt so that the company can develop its business more broadly. Based on agency theory, managers as agents are responsible for optimizing revenue if the company's finances are at high risk by reducing costs, including costs for CSR. A decrease in CSR costs results in a decrease in CSR information disclosure. While on the other hand, the interests of stakeholders to know the manager must also fulfill the form of corporate responsibility. The difference in interests can lead to agency conflict (Hidayat, 2017).

This study's results indicate that there is no influence between leverage and CSR disclosure, so $\mathrm{H} 3$ is rejected and fails to support agency theory. The company can use the amount of debt received for internal purposes such as repairing machinery, transportation, or developing and fulfilling business strategies, including social and environmental missions. Unfortunately, the mining company's operational activities are directly related to natural resources. They cannot hinder from damaging nature; thus, Law of the Republic of Indonesia No. 4 of 2009 concerning Mineral and Coal Mining formed, companies required to allocate the CSR program. What is more, the sample in the study is a large mining company and goes public, so the amount of leverage has nothing to do with CSR disclosure. The same results were revealed in the research of Chek et al. (2013), Chauhan and Amit (2014) and Hidayat (2017)

\subsection{Board of Commissioners and CSR Disclosure}

The board of commissioners is the representative of shareholders who have the authority to oversee directors' performance. Based on stakeholder theory, the board of commissioners is a party that can influence the directors in the management of the company's business to suit the interests of each stakeholder.

The results of the data analysis and hypothesis testing showed no influence between the size of the board of commissioners and CSR disclosure, so the $\mathrm{H} 4$ research was rejected and failed to support stakeholder theory. According to Effendi et al. (2012), the board of commissioners' intervention on management related to CSR disclosure is not very visible because the board of commissioners tend to oversee management in managing finances rather than non-financial activities such as social activities. According to Singgih et al. (2017), supervision by the board of commissioners regarding CSR disclosures is not adequate. It is more focused on providing direction and advice related to corporate financial management. Suryahadi (2017) reports mining companies' financial condition in Indonesia 
during 2017. Statistical bureau reports also show that almost all business sectors experience positive growth, yet it doesn't happen in the mining sector. This trend continues in 2019 that Suryahadi (2020) blames the mining sector index as one of the reasons for the IDX composite drop. The index experiences negative growth until $12,83 \%$. The contribution of the mining sector to GDP decreased from $7,77 \%$ to $7,38 \%$. In this situation, it makes sense that companies might ignore any other aspect and focus on profit. This report shows that the mining sector needs to bring back the growth.

Besides, not all independent commissioners can show their independence in carrying out their supervisory functions. This led to a reduction in the encouragement of the board of commissioners towards management to disclose social activities (Eriandani \& Kuswanto, 2016). Thus, the number of commissioners serving does not affect the company's decision to disclose CSR information.

The company is aware of its environmental and social responsibilities and can decide how to fulfill these responsibilities without seeing how many boards of commissioners work for the company. The same results were revealed in the research of $\mathrm{Vu}$ and Buranatrakul (2018) and Novitasari and Bernawati (2020).

\section{Conclusion and Recommendation}

While other sectors succeeded in proving the four hypotheses, however, not in the mining sector, the analysis supports the argument that foreign investors consider the social issues, as reflected in the CSR report. This study also gives additional proof of the company size effect toward CSR disclosure. However, the third and fourth hypotheses were rejected. There is no effect of leverage toward corporate social responsibility disclosure. Board of commissioners also does not affect the disclosure of corporate social responsibility.

For the next research, we suggest adding other independent variables related to CSR disclosure such as environmental performance and since it is relevant to mining sector issues as well as use other more objective CSR measurements. Some researchers also use zero foreign ownership as their sample. By including this data as a sample, the amount of sample will be more substantial. The number of research samples may affect the results of the study. It is more logical to add the number of the samples by adding the study period. While the public expects companies to be more concerned and transparent about disclosing CSR programs, the company that exploits natural resources should make a significant difference to the society and the environment. The company should hire a board commissioner who has a sense for social issues.

\section{References}

Amelia, A. R. (2019). Oil, gas and mining companies are subject to sanctions for environmental pollution. Retrieved July 28, 2020, from https://katadata.co.id/arnold/energi/5e9a55526efa2/11perusahaan-migas-dan-tambang-terkena-sanksi-pencemaranlingkungan

Asrida, W. (2011). The effect of government share ownership and foreign share ownership on the disclosure of corporate social responsibility with company size and profitability as control variables. Accounting journal, 3(2), 652-668. https://doi. org/10.17509/jaset.v3i2.10076

Cahyani, C., \& Suryaningsih, R. (2016). The effect of leverage, board of commissioner, foreign ownership, company age, and company size towards the disclosure of corporate social responsibility (CSR) implementation. Global Academy of Training and Research Journal, 1(1), 27-33. https://http:// gatrenterprise.com/GATRJournals/afr_vol1_2016_issue1.html

Carroll, A. B. (1991). The pyramid of corporate social responsibility: Toward the moral management of organizational stakeholders. Business Horizons, 34(4), 39-48. https://doi.org/10.1016/00076813(91)90005-G

Central Bureau of Statistics. (2017). Number of manpower by field category. Retrieved July 28, 2020, from https:// databoks.katadata.co.id/datapublish/2017/05/02/inilah-sektorterbanyak-menyerap-tenaga-kerja

Chauhan, S., \& Amit. (2014). A relational study of firm's characteristics and CSR expenditure. Procedia Economics and Finance, 11(14), 23-32. https://doi.org/10.1016/S22125671(14)00172-5

Chek, I. T., Mohammad, Z. Z., Jammal, \& Norwani, N. M. (2013). Corporate social responsibility (CSR) disclosure in consumer products and plantation industry in Malaysia. American International Journal of Contemporary Research, 3(5), 118-125.

Chelsya, C. (2018). Effect of profitability, company size, and size of the board of commissioners on corporate social responsibility disclosure in manufacturing companies listed on the Indonesian stock exchange. Journal of Economics, 23(1), 141-153. https:// doi.org/10.24912/je.v23i1.339

Do, A. (2017). The effect of foreign equity ownership on corporate social responsibility: empirical evidence from Poland. Financial Internet Quarterly, 13(3), 66-75. https://doi.org/10.1515/fiqf2016-0030

Effendi, B., Uzliawati, L., \& Yulianto, A. S. (2012). The effect of the board of commissioners on the environmental disclosure of manufacturing companies listed on the IDX 2008-2011. Accounting National Symposium 15. https://doi. org/10.1186/1476-4598-10-45

Effendi, M. A. (2018). The power of good corporate governance (2nd ed.). Jakarta, Indonesia: Salemba Empat.

Eriandani, R., \& Kuswanto, C. (2016). Does the composition of the board of directors and the board of commissioners affect the 
disclosure of corporate social responsibility (CSR)? Expansion. Journal of Economics, Finance, Banking and Accounting, 8(2), 213-227.

Giannarakis, G. (2014). Corporate governance and financial characteristic effects on the extent of corporate social responsibility disclosure. Social Responsibility Journal, 10(4), 569-590. https://doi.org/10.1108/SRJ-02-2013-0008

Habbash, M. (2016). Corporate governance and corporate social responsibility disclosure: evidence from Saudi Arabia. Journal of Economic and Social Development, 3(1), 87-103. https:// doi: 10.1504/IJCSSR.2017.10005240

Hermawan, A., \& Gunardi, A. (2019). Motivation for disclosure of corporate social responsibility: evidence from banking industry in Indonesia. Entrepreneurship and Sustainability Issues, 6(3), 1297-1306. https://doi.org/http://doi.org/10.9770/ jesi.2018.6.3(17)

Hidayat, W. W. (2017). The influence of size, return on equity, and leverage on the disclosure of the corporate social responsibility (CSR). International Journal of Education and Research, 5(8), 57-66. https://www.ijern.com/journal/2017/August-2017/06.pdf

Hu, Y. Y., Zhu, Y., \& Hu, Y. (2016). Does ownership type matter for corporate social responsibility disclosure: evidence from China. Global Conference on Business and Finance Proceedings, 11(1), 183-197. https://doi.org/10.1111/j.1467-8683.2011.00907

Jahid, A., Rashid, H. U., \& Hossain, S. Z. (2020). Impact of corporate governance mechanisms on corporate social responsibility disclosure of publicly-listed banks in Bangladesh. Journal of Asian Finance, Economics and Business, 7(6), 61-71. https:// doi.org/10.13106/jafeb.2020.vol7.no6.061

Jain, A., Keneley, M., \& Thomson, D. (2015). Voluntary CSR disclosure works! Evidence from Asia-Pacific banks. Social Responsibility Journal, 11(1), 2-18. https://doi.org/10.1108/ SRJ-10-2012-0136

Jensen, M. C., \& Meckling, W. H. (1976). Theory of the firm: managerial behavior, agency costs, and ownership structure. Journal of Financial Economics, 3(4), 305-360. https://doi. org/10.1016/0304-405x(76)90026-x

Kang, E., \& Hwang, H.-J. (2018). Strategic management plan for transnational organizations. Journal of Asian Finance, Economics and Business, 5(2), 119-128. https://doi. org/10.13106/jafeb.2018.vol5.no2.119

Kompas. (2016). The DPR has prepared a law on CSR, the company will be charged 2 percent to 3 percent. Retrieved December 27, 2019, from https://nasional. kompas.com/read/2016/04/25/09114111/DPR.Siapkan. UU.soal.CSR.Perusahaan.Akan.Dibebankan.2.Persen. hingga.3.Persen?page=all

Kotler, P., \& Lee, N. (2005). Corporate social responsibility: Doing the most good for your company and your cause. Hoboken, NJ: John Wiley and Sons, Inc.

Lee, J., Kim, S. J., \& Kwon, I. (2017). Corporate social responsibility as a strategic means to attract foreign investment: evidence from Korea. Sustainability, 9(11), 1-11. https://doi. org/10.3390/su9112121

Mousa, G. A., \& Hassan, N. T. (2015). Legitimacy theory and environmental practices: short notes. International Journal of Business and Statistical Analysis. https://doi.org/10.12785/ ijbsa/020104

Nawaiseh, M. E., Also, S. S., \& El-shohnah, R. A. Z. Y. (2015). Influence of firm size and profitability on corporate social responsibility disclosures by banking firms (CSRD): evidence from Jordan. Journal of Applied Finance and Banking, 5(6), 97-111. https://http://www.scienpress.com/Upload/JAFB/ Vol\%205_6_6.pdf

Nguyen, A. H., \& Nguyen, L. H. (2020). Determinants of sustainability disclosure: empirical evidence from Vietnam. Journal of Asian Finance, Economics and Business, 7(6), 7384. https://doi.org/10.13106/jafeb.2020.vol7.no6.073

Nguyen, S. La, Pham, C. D., Nguyen, A. H., \& Dinh, H. T. (2020). Impact of corporate social responsibility disclosures on bankruptcy risk of Vietnamese firms. Journal of Asian Finance, Economics and Business, 7(5), 81-90. https://doi.org/10.13106/ jafeb.2020.vol7.no5.081

Novitasari, D., \& Bernawati, Y. (2020). The impact of good corporate governance on the disclosure of corporate social responsibility. International Journal, 10(12), 265-276. https://https://www. ijicc.net/images/vol10iss12/101220_Novitasari_2020_E_R. pdf

Oktavianawati, L., \& Wahyuningrum, I. F. S. (2019). Factors affecting corporate social responsibility (CSR) disclosure. Accounting Analysis Journal, 8(2), 110-117. https://doi. org/10.15294/aaj.v8i2.22745

Priyanka, A. (2019). The mining industry fell 1.70 percent. https:// republika.co.id/berita/pvr5mp370/industri-pertambanganturun-170-persen

Prahalad, C. K., \& Hammond, A. (2002). Serving the World's Poor, Profitably. Harvard Business Review, 80(9), 48-57.

Sembiring, E. R. (2005). Company characteristics and social responsibility disclosures: empirical study on companies listed on the Jakarta stock exchange. 8th National Symposium on Accounting, September, 15-16.

Singh, M., Farida, L., \& Iwanda, R. A. (2017). The determinant of the level of social responsibility disclosure of the food and beverage sub-sector manufacturing companies on the IDX. Journal of Business and Management, 11(3), 259270. https://doi.org/10.19184/bisma.v11i3.6320

Suastha, R. D. (2016). The quality of CSR of Indonesian companies is low. CNN Indonesia. Retrieved November 29, 2019, from https:// www.cnnindonesia.com/nasional/20160721074144-20-146030/ riset-temukan-kualitas-csr-perusahaan-indonesia-rendah

Sunreni. (2016). The effect of foreign ownership and profitability on corporate social responsibility (CSR) disclosure in mining sector companies listed on the IDX. Journal of Economic and Management Scienties, 1(1), 47-59. 
Suryahadi, A. (2017). The mining sector in the first quarter of 2017 is increasingly sluggish. kontan.co.id. Retrieved August 10, 2020, from https://nasional.kontan.co.id/news/sektorpertambangan-kuartal-i-2017-makin-lesu.

Suryahadi, A. (2020). Sepanjang 2019: The mining sector has dropped dramatically, this is the prospect in 2020. Retrieved August 10, 2020, from https://investasi.kontan.co.id/news/.

Vu, K. A., \& Buranatrakul, T. (2018). Corporate social responsibility disclosure in Vietnam: A longitudinal study. DLSU Business and Economics Review, 27(2), 147-165.
Waluyo, W. (2017). Firm size, firm age, and firm growth on corporate social responsibility in Indonesia: The case of real estate companies. European Research Studies Journal, 20(4A), 360-369.

Yoon, B., \& Lee, J. (2019). Corporate social responsibility and information asymmetry in the Korean market: Implications of chaebol affiliates. Journal of Asian Finance, Economics and Business, 6(1), 21-31. https://doi.org/10.13106/jafeb.2019. vol6.no1.21 